\title{
Strategi manajemen sekolah dalam menghadapi pemberlakuan sistem zonasi
}

\section{Ya Shinta Dewi Wahyuni, Nurhadi Nurhadi *, Okta Hadi Nurcahyono}

Fakultas Keguruan dan Ilmu Pendidikan, Universitas Sebelas Maret.

J1. Insinyur Sutami No. 36 A, Kentingan, Jebres, Surakarta, Jawa Tengah 57126, Indonesia.

* Corresponding Author. E-mail: nurhadi@staff.uns.ac.id

\section{ARTICLE INFO \\ Article History \\ Received: \\ 18 May 2020; \\ Revised: \\ 6 August 2020; \\ Accepted: \\ 10 August 2020 \\ Available online: \\ 25 September 2020}

\section{Keywords}

Adaptasi;

Budaya sekolah;

Manajemen sekolah;

Sistem zonasi;

Adaptation;

School culture;

School management;

Zoning system

\begin{abstract}
Penelitian ini bertujuan untuk mengetahui perubahan-perubahan yang terjadi setelah sistem zonasi di terapkan di SMA Negeri (SMAN) 1 Surakarta dan menganalisa strategi manajemen sekolah di SMAN 1 Surakarta dalam menghadapi pemberlakuan sistem zonasi menggunakan teori struktural fungsional oleh Radcliffe-Brown. Penelitian ini menggunakan pendekatan etnografi dengan metode penelitian kualitatif. Analisis data yang digunakan dalam penelitian ini menggunakan model analisis interaktif Miles dan Huberman melalui beberapa prosedur kegiatan meliputi reduksi data, penyajian data, serta penarikan kesimpulan atau verifikasi. Hasil penelitian menunjukkan: 1.) Perubahan input siswa yang menjadi relatif heterogen setelah sistem zonasi diterapkan menyebabkan perubahan budaya sekolah dan pola pembelajaran; 2.) Strategi yang digunakan oleh manajemen sekolah di SMAN 1 Surakarta dalam menghadapi perubahan budaya sekolah adalah dengan penanaman nilai-nilai yang terdapat dalam Hasthalaku dan inovasi Gerakan Literasi Sekolah (GLS); dan 3.) Mekanisme adaptif dengan mengubah metode pembelajaran dan wacana akan diterapkannya Sistem Kredit Semester (SKS) di SMAN 1 Surakarta merupakan strategi yang dipilih oleh manajemen sekolah dalam rangka menghadapi perubahan pola pembelajaran.
\end{abstract}

This study aims to: 1.) Know the changes that occur after the zoning system is implemented in SMAN 1 Surakarta; 2.) Analyzing the school management strategy at SMAN 1 Surakarta in dealing with implementing the zoning system using functional, structural theory by Radcliffe-Brown. This study uses an ethnographic approach with qualitative research methods. Analysis of the data used in this study uses a number of procedure activities, including data reduction, data presentation, and drawing conclusions or verification. Results of the study: (1) Changes in student input that become relatively heterogeneous after the zonation system is applied causes changes in school culture and learning patterns; 2.) The strategy used by school management at SMAN 1 Surakarta in dealing with changes in school culture is by inculcating the values contained in Hasthalaku and innovating the School Literacy Movement (GLS); and 3.) The adaptive mechanism by changing learning methods and discourse will be applied to the Semester Credit System (SKS) at SMAN 1 Surakarta is the strategy chosen by the school management in order to deal with changes in learning patterns.

This is an open access article under the CC-BY-SA license.

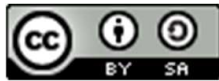

How to cite:

Wahyuni, Y. S. D., Nurhadi, N., \& Nurcahyono, O. H. (2020). Strategi manajemen sekolah dalam menghadapi pemberlakuan sistem zonasi. Jurnal Akuntabilitas Manajemen Pendidikan, 8(2), 124-136. doi: https://doi.org/10.21831/jamp.v8i1.31858 


\section{PENDAHULUAN}

Indonesia merupakan salah satu negara yang masih berkembang dalam berbagai segmen kehidupan, salah satunya adalah di bidang Pendidikan. Pendidikan di Indonesia masih terus mengalami perubahan baik dari segi kebijakan atau sistem yang di implementasikan. Atas dasar Peraturan Kementerian Pendidikan dan Kebudayaan Republik Indonesia Nomor 17 tahun 2017 tentang Penerimaan Peserta Didik Baru (PPDB), Kementerian Pendidikan dan Kebudayaan Republik Indonesia telah mengeluarkan program Penerimaan Peserta Didik Baru (PPDB) melalui sistem zonasi. Sistem zonasi membuat pemerintah daerah mewajibkan sekolah-sekolah yang berada di bawah naungannya untuk menerima calon peserta didik yang tinggal pada radius zona terdekat dari sekolah paling sedikit sebesar $90 \%$ dari total jumlah peserta didik yang diterima (Chan, Rimba, Setiawati, Nurfitriana, Dawiyah, ... Nandatulloh, 2019, p. 327). Diketahui terdapat perubahan kebijakan yang dilakukan oleh Menteri Pendidikan dan Kebudayaan Republik Indonesia yang baru, Nadiem Anwar Makarim mengenai sistem zonasi. Perubahan tersebut dilakukan berdasarkan evaluasi dari sistem zonasi yang telah diteberlakukan sebelumnya dan juga disebabkan tidak semua daerah siap menjalankan kebijakan sistem zonasi. Perubahan tersebut dapat dilihat pada Tabel 1.

Tabel 1. Perubahan Kebijakan Sistem Zonasi

\begin{tabular}{cccc}
\hline No & Tahun & Jalur & Kuota \\
\hline 1 & 2017 & Zonasi & $90 \%$ \\
& & Prestasi & $5 \%$ \\
2 & \multirow{2}{*}{2018} & Lainnya & $5 \%$ \\
& & Zonasi & $90 \%$ \\
& \multirow{2}{*}{2019} & Prestasi & $5 \%$ \\
3 & & Lainnya & $5 \%$ \\
& & Zonasi & $80 \%$ \\
& \multirow{2}{*}{2020} & Prestasi & $15 \%$ \\
& & Lainnya & $5 \%$ \\
& & Zonasi & $50 \%$ \\
& & Prestasi & $30 \%$ \\
& & Lainnya & $20 \%$ \\
\hline
\end{tabular}

Sumber: Kementerian Pendidikan dan Kebudayaan Republik Indonesia (2020)

Berdasarkan pada Tabel 1, dapat diketahui bahwa dari tahun 2017 sampai dengan tahun 2020 terdapat perubahan kuota Penerimaan Peserta Didik Baru (PPDB) melalui sistem zonasi yang dikategorikan menjadi tiga jalur penerimaan. Pada tahun 2017-2018, ketiga jalur penerimaan sistem zonasi masih memiliki kuota yang sama dan tidak mengalami perubahan. Dimana sekolah wajib menerima minimal $90 \%$ peserta didik berdasarkan jalur zonasi atau yang berdomisili pada radius zona terdekat dengan sekolah sesuai dengan kondisi di daerah tersebut. Kuota $10 \%$ sisanya, dibagi menjadi $5 \%$ peserta didik yang diterima melalui jalur prestasi dan 5\% melalui jalur perpindahan tugas orang tua/wali.

Perubahan komposisi kuota PPDB ditunjukkan pada grafik tahun 2019 dan 2020. Pada Peraturan Kementrian Pendidikan dan Kebudayaan Republik Indonesia Nomor 51 Tahun 2018 dan Peraturan Kementrian Pendidikan dan Kebudayaan Republik Indonesia Nomor 20 Tahun 2019, terdapat pengurangan kuota PPDB melalui jalur zonasi menjadi $80 \%$. Selanjutnya, jalur prestasi diberi tambahan kuota sebanyak $15 \%$ dan sisanya $5 \%$ melalui jalur perpindahan tugas orang tua atau wali. Dalam Permendikbud PPDB terbaru, yaitu Peraturan Kementrian Pendidikan dan Kebudayaan Republik Indonesia Nomor 44 Tahun 2019 dapat diketahui bahwa jalur zonasi kembali mengalami pengurangan kuota menjadi minimal 50\% peserta didik yang diterima melalui jalur ini. Sebaliknya, tambahan kuota terjadi pada jalur prestasi yang mengalami peningkatan menjadi maksimal $30 \%$, baik berdasarkan nilai UN atau prestasi akademik maupun nonakademik. Jalur lain sisanya sebanyak $20 \%$ dibagi lagi menjadi jalur afirmasi minimal $15 \%$ dan jalur perpindahan tugas orang tua atau wali maksimal 5\%. 
Beberapa pertimbangan Pemerintah Pusat Republik Indonesia dalam melakukan perubahan komposisi PPDB tersebut karena melihat bahwa untuk mencapai jalur zonasi minimal $80 \%$ Pemerintah Daerah masih mengalami kesulitan. Maka dari itu, satuan zona diperbesar dari satu kota menjadi satu zona untuk menghindari adanya sekolah yang tidak mendapatkan siswa. Selain itu, belum meratanya kualitas pendidikan di Indonesia seperti penyebaran guru dan kelayakan sarana prasarana sekolah juga menjadi penyebab pemerintah melakukan berbagai perubahan kebijakan pendidikan (Kementerian Pendidikan dan Kebudayaan Republik Indonesia, 2020).

Pada beberapa penelitian yang telah dilakukan sebelumnya mengenai sistem zonasi, Adiputra, Karsidi, dan Haryono (2019) menerangkan bahwa program Penerimaan Peserta Didik Baru (PPDB) online dengan sistem zonasi menjadi salah satu strategi yang digunakan pemerintah untuk mencapai pemerataan pendidikan secara cepat dan berkualitas melalui reformasi sekolah secara menyeluruh. Disamping itu, sistem zonasi juga menimbulkan berbagai dampak positif maupun negatif. Chan et al. (2019, p. 330) menyimpulkan bahwa dampak positif sistem zonasi adalah menghilangkan labelling atas sekolah unggul dan non-unggul. dampak negatifnya adalah wali murid masih megalami kesulitan untuk mendaftarkan anaknya secara online. Hal tersebut selaras dengan penelitian yang dilakukan di SMP Negeri di Kabupaten Pamekasan bahwa Pelaksanaan PPDB menggunakan sistem zonasi di Kabupaten Pamekasan masih belum maksimal dalam hal pelayanan terhadap masyarakat, seperti kurangnya sosialisasi tentang radius zona yang ditetapkan atau pengertian sistem zonasi turut menimbulkan kebingungan publik karena belum ada petunjuk teknis mengenai pelaksanaan PPDB sistem zonasi (Hasbullah \& Anam, 2019, p. 121)

Melihat pada berbagai penelitian tersebut, reformasi sekolah secara menyeluruh dengan sistem zonasi tidak hanya membutuhkan peran pemerintah, namun juga sekolah dan masyarakat. Hal ini melihat bahwa sistem zonasi menjadi bahan yang banyak diperbincangkan masyarakat luas karena menuai pro dan kontra. Di satu sisi, sistem zonasi dinilai membatasi siswa yang memiliki nilai tinggi untuk mendapatkan sekolah yang diinginkan seperti sekolah favorit atau sekolah unggulan. di sisi lain, Kementerian Pendidikan dan Kebudayaan Republik Indonesia (Kemendikbud RI) mengatakan bahwa tujuan dari perancangan kebijakan ini adalah untuk menciptakan pemerataan pendidikan dan menghilangkan konsep sekolah favorit (Pratiwi, 2019). Sistem zonasi yang beorientasi untuk menghilangkan kastanisasi pendidikan dan memeratakan kualitas pendidikan berbagai daerah di Indonesia menjadi terobosan besar sebagai antitesis dari sistem pendidikan kolonial yang cenderung diskriminatif dan tidak berkeadilan. Perubahan-perubahan yang muncul pasca pember-lakuan sistem zonasi turut mempengaruhi perubahan budaya sekolah yang bersangkutan, salah satunya yang terjadi di SMA Negeri 1 Surakarta.

SMAN 1 Surakarta merupakan salah satu sekolah menengah atas di Surakarta yang menerapkan sistem zonasi dalam proses Penerimaan Peserta Didik Baru (PPDB) secara online. Sebelum sistem zonasi diberlakukan di SMAN 1 Surakarta, sekolah ini menjadi incaran calon peserta didik yang memiliki nilai akademis atau kompetensi tinggi karena di kenal sebagai sekolah favorit. Akan tetapi, setelah SMAN 1 Surakarta memberlakukan sistem zonasi, sekolah ini harus menerima calon peserta didik yang utamanya berasal dari domisili atau tempat tinggal dengan radius zona terdekat yang memiliki capaian kompetensi yang beragam, baik dari segi nilai, kemampuan beradaptasi dengan kultur sekolah, perilaku, atau kemampuan lainnya. Meski tidak dipungkiri masih terdapat calon peserta didik yang dapat masuk melalui jalur prestasi, namun terdapat perbedaan ketika sekolah ini melakukan proses seleksi berdasarkan nilai atau prestasi murni. Perbedaan proses seleksi tersebut menyebabkan berbagai perubahan yang ada seperti perubahan budaya sekolah yang menyangkut proses pembelajaran, aktivitas rutin siswa, bahkan juga turut mempengaruhi output yang dihasilkan oleh sekolah.

Pada beberapa penelitian mengenai budaya sekolah, Widodo (2017) dalam artikelnya menyimpulkan bahwa budaya sekolah dimaknai sebagai tradisi sekolah yang tumbuh dan berkembang sesuai dengan spirit dan nilai-nilai yang dianut di sekolah. Munculnya budaya sekolah tidak lepas dari peran unsur-unsur manajemen sekolah seperti kepala sekolah, guru, siswa, serta komite sekolah yang membentuk budaya tersebut. Penelitian mengenai budaya sekolah juga dapat dilihat pada artikel yang ditulis oleh Izzah dan Harmanto (2013) yang dilakukan di SMP Negeri 38 Surabaya, bahwa sekolah tersebut membentuk budaya sekolah melalui proses pembiasaan yang dilakukan sehari-hari. Salah satu budaya sekolah yang dibentuk adalah penanaman nilai-nilai 
antikorupsi yang di gambarkan melalui pembiasaan bersikap jujur di kantin kejujuran, buku pengendali ketertiban dan kedisiplinan, serta kegiatan pembelajaran. Seiring berjalannya waktu, budaya sekolah akan turut mempengaruhi karakter peserta didik untuk berlatih bersikap jujur baik dalam bersosialisasi di lingkungannya atau saat kegiatan pembelajaran berlangsung. Hal tersebut selaras dengan penelitian yang dilakukan oleh Winarto dan Prasojo (2017), menyatakan bahwa sekolah sebagai organisasi pembelajar memiliki fungsi dan perannya tersendiri dalam membentuk sikap dan perilaku peserta didik dalam proses pembelajaran. Proses tersebut dapat dibentuk melalui manajemen budaya belajar yang diterapkan oleh masing-masing sekolah (Winarto \& Prasojo, 2017, p. 110).

Manajemen sekolah atau Otonomi Manajemen Sekolah (OMS) merupakan inisiatif pemerintah dalam menerapkan konsep desentralisasi pendidikan yang pengelolaannya menunjukkan semangat desentralisasi dan reformasi manajemen pendidikan sampai ke tingkat sekolah. Dimana sekolah dalam hal ini dilihat sebagai lembaga otonom yang penyelenggaraannya tetap berada pada koridor Sistem Pendidikan Nasional (Danim, 2010). Konsep manajemen sekolah memiliki semangat yang sama dengan tujuan dari diterapkannya sistem zonasi, yaitu mereformasi pendidikan di Indonesia secara menyeluruh yang melibatkan peran serta pemerintah daerah dan sekolah, tidak hanya pemerintah pusat yang memiliki wewenang dalam menentukan kebijakan sekolah seperti yang terdapat dalam tradisi sentralisasi pendidikan sebelumnya. Manajemen sekolah memiliki fungsi sebagai suatu karakteristik pendidikan yang muncul dari kebutuhan untuk memberikan arahan pada perkembangan, baik secara kualitatif maupun kuantitatif dalam operasional sekolah (Rohiat, 2012).

Oleh karena itu dalam prosesnya, manajemen sekolah membutuhkan strategi yang dapat digunakan untuk menghadapi pemberlakuan sistem zonasi seperti yang ada di SMAN 1 Surakarta. Dimana sistem zonasi tidak hanya berdampak pada perubahan budaya sekolah atau kultur sekolah, namun juga perilaku atau karakter peserta didik dan pendidik. Adiputra, Karsidi, dan Haryono (2019), menyebutkan bahwa sistem zonasi memunculkan cultural lag seperti ketidaksiapan peserta didik baru dalam menghadapi sistem zonasi yang mengharuskan calon peserta didik mendaftarkan dirinya secara online. Melalui analisinya dengan mengunakan Teori Ogburn yang meyatakan bahwa manusia akan mengalami cultural lag jika tidak adaptif terhadap perkembangan zaman, maka sistem zonasi akan memunculkan adanya ketimpangan-ketimpangan budaya jika calon peserta didik tidak siap akan perubahan sistem teknologi tersebut (Adiputra, Karsidi, \& Haryono, 2019, p. 3).

Melihat pada berbagai dampak sistem zonasi tersebut, urgensi sekolah untuk menerapkan berbagai strategi dalam menghadapi pemberlakuan sistem zonasi perlu dilakukan. Strategi tersebut dilakukan oleh berbagai unsur yang ada dalam manajemen sekolah agar tidak terjadi culture lag dalam proses pembelajaran di sekolah. Beberapa penelitian tentang strategi manajemen sekolah seperti yang dilakukan oleh Sulistyoningrum (2016) menyimpulkan bahwa strategi yang dapat dilakukan oleh sekolah dalam rangka mengoptimalkan segala kekuatan dan peluang yang dimiliki untuk mengatasi beragam kelemahan dan ancaman yang dihadapi antara lain adalah: 1.) Mengoptimalkan proses akedemik; 2.) Peningkatan kualitas profesional guru; dan 3.) Menjalin relasi yang baik dengan pihak-pihak lain seperti pemerintah dan warga masyarakat (Sulistiyoningrum, 2016, pp. 111-112).

Adapun langkah-langkah yang diambil agar strategi yang diterapkan dapat berhasil sesuai dengan tujuannya, maka semua unsur-unsur yang ada dalam manajemen sekolah seperti kepala sekolah, siswa, guru, dan komite sekolah harus menjalankan peran sesuai dengan tupoksinya. Hal ini salah satunya dapat dilihat pada penelitian yang dilakukan di SMA Negeri 1 Kuantan Hilir. Strategi pengembangan organisasi di SMA Negeri 1 Kuantan Hilir dapat dikatakan terlaksana dengan baik. Pelaksanaan strategi tersebut dilakukan dengan memperhatikan pembagian tugas yang diberikan kepada setiap individu yang ada didalam organisasi. Adanya pembagian tugas yang jelas kepada setiap unsur dalam organisasi tersebut serta didukung dengan penyusunan struktur organisasi yang jelas pula, maka setiap unsur dalam manajemen sekolah atau organisasi tersebut juga paham bagaimana mereka harus mempertanggungjawabkan pekerjaannya (Tuindra \& Sahuri, 2013, p. 113).

Penelitian ini bertujuan untuk mengetahui strategi manajemen sekolah yang ada di SMA Negeri 1 Surakarta dalam menghadapi pemberlakuan sistem zonasi. Melalui penelitian ini, diharapkan sekolah dapat memetakan berbagai perubahan yang ditimbulkan dari sistem zonasi yang 
diterapkan, serta dapat mengevaluasi kekurangan dan kelebihan dari strategi manajemen sekolah yang digunakan untuk mempertahankan dan memperbaiki kualitas mutu pendidikan.

\section{METODE}

Penelitian ini merupakan jenis penelitian kualitatif yang dilakukan dengan menggunakan pendekatan etnografi. Pendekatan etnografi dapat digunakan oleh peneliti untuk memahami cara orang-orang berinteraksi dan bekerjasama melalui fenomena yang diamati dalam kehidupan seharihari. Dalam hal ini, peneliti dapat mengetahui bagaimana unsur-unsur manajemen sekolah bekerja sama dalam memainkan fungsinya sesuai dengan status yang dimiliki untuk menerapkan strategistrategi dalam menghadapi pemberlakuan sistem zonasi. Penelitian ini dilakukan di SMAN 1 Surakarta sejak bulan September 2019. Sekolah tersebut dipilih karena SMAN 1 Surakarta merupakan salah satu sekolah yang menerapkan sistem zonasi sejak pemerintah pertama kali mengeluarkan program ini, yaitu pada tahun 2017. Selain itu SMA Negeri 1 Surakarta merupakan sekolah yang relevan dengan topik penelitian, yaitu terjadi perubahan budaya sekolah pasca pemberlakuan sistem zonasi yang melibatkan unsur-unsur manajemen sekolah tersebut.

Subjek penelitian ini ditentukan berdasarkan teknik purposive sampling, yaitu kepala sekolah, siswa, guru, dan komite sekolah. Subjek penelitian tersebut ditentukan atas dasar pertimbangan-pertimbangan tertentu bahwa mereka merupakan unsur-unsur pokok yang ada dalam manajemen sekolah yang dikenai dampak langsung dari adanya sistem zonasi. Selain itu, untuk menguji validitas data peneliti menggunakan metode triangulasi. Triangulasi sumber dilakukan kepada informan atau subjek penelitian lain yang telah ditentukan seperti waka kurikulum, waka humas, waka kesiswaan, dan alumni SMAN 1 Surakarta. Informan ini dipilih karena memiliki pengetahuan dan memahami persoalan mengenai perubahan budaya sekolah yang terjadi. Selain triangulasi sumber, triangulasi metode juga dilakukan dengan cara melakukan cross-check data di lapangan apakah data yang dikumpulkan melalui proses wawancara, observasi, dan studi dokumentasi memiliki kesesuaian yang sama.

Instrumen dalam penelitian adalah peneliti sendiri yang melakukan observasi langsung di lapangan dalam melakukan pengumpulan data. Selain itu, pengumpulan data juga dilakukan dengan menggunakan teknik wawancara dan analisis dokumen atau studi dokumentasi. Akibat munculnya beberapa hambatan yang berada di luar kendali peneliti seperti pandemi virus Covid-19 yang mengharuskan rakyat Indonesia untuk melakukan social distancing dan beberapa daerah lain juga telah memberlakukan sistem lockdown, maka proses wawancara dan studi dokumentasi lain yang belum selesai dilanjutkan dengan cara daring (dalam jaringan) seperti komunikasi via aplikasi Whatsapp. Data yang dikumpulkan dalam penelitian ini berupa perubahan-perubahan yang terjadi pasca pemberlakuan sistem zoansi, proses kerjasama, serta kegiatan-kegiatan yang dilakukan oleh unsur-unsur manajemen sekolah dalam kaitannnya dengan pemberlakuan sistem zonasi. Data yang telah dikumpulkan kemudian dianalisis menggunakan teknik analisis data menurut Miles dan Huberman. Analisis data kualitatif menurut Miles dan Huberman meliputi tiga prosedur kegiatan, yaitu reduksi data, penyajian data, serta penarikan kesimpulan atau verifikasi (Ulfatin, 2014).

Reduksi data dilakukan dengan memilih, menyederhanakan, dan menseleksi data pada halhal inti yang diperoleh di lapangan. Data yang direduksi meliputi perubahan-perubahan yang terjadi setelah sistem zonasi diterapkan di SMAN 1 Surakarta serta usaha-usaha manajemen sekolah dalam beradaptasi dengan perubahan budaya sekolah dan pola pembelajaran akibat pemberlakuan sistem zonasi tersebut. Setelah itu, penyajian data dilakukan oleh peneliti dengan cara menyusun data dari sekumpulan informasi yang diperoleh dari hasil reduksi data, kemudian diolah dan disajikan dalam bentuk table atau kata-kata secara naratif. Kemudian yang terakhir adalah penarikan kesimpulan atau verifikasi. Peneliti disini menganalisis data sesuai dengan apa yang telah disajikan pada tahapan sebelumnya dan mendeskripsikan bagaimana sistem zonasi menimbulkan berbagai dampak perubahan seperti perubahan budaya sekolah yang mengharuskan sekolah untuk menerapkan berbagai strategi agar dapat mempertahankan dan meningkatkan kualitas mutu sekolah. Kesimpulan ini didasarkan pada data yang diperoleh oleh peneliti baik dari proses wawancara, observasi, maupun studi dokumentasi. 


\section{HASIL DAN PEMBAHASAN}

Hasil

\section{Deskripsi Pemberlakuan Sistem Zonasi di SMAN 1 Surakarta}

Sistem zonasi di SMAN 1 Surakarta telah di berlakukan sejak dua tahun terakhir ini. Sesuai dengan Keputusan Kepala Dinas Pendidikan dan Kebudayaan Provinsi Jawa Tengah Nomor 421/07651 tentang Petunjuk Teknis Penerimaan Peserta Didik Baru (PPDB) pada Sekolah Menengah Atas (SMA) dan Sekolah Menengah Kejuruan (SMK) Negeri Provinsi Jawa Tengah Tahun Pelajaran 2019/2020, seleksi PPDB SMA dilaksanakan melalui tiga jalur, yaitu jalur zonasi, jalur prestasi, dan jalur perpindahan orang tua atau wali. Hanya saja, perbedaannya adalah pada tahun pertama, sistem zonasi yang diterapkan menggunakan cakupan wilayah Kecamatan dengan sistem pemeringkatan masih menggunakan nilai UN SMP. pada tahun kedua, cakupan wilayah yang digunakan berubah menjadi wilayah Desa atau Kelurahan dalam jarak terdekat dengan satuan Pendidikan tanpa menggunakan pemeringkatan nilai UN SMP dalam proses seleksi.

Melalui petunjuk teknis (juknis) PPDB tahun 2019/2020 tersebut, calon peserta yang wajib diterima melalui jalur zonasi adalah calon peserta didik yang berdomisili pada jarak Desa atau Kelurahan terdekat dalam zona sekolah paling sedikit $90 \%$ dari total jumlah keseluruhan peserta didik yang diterima. Domisili calon peserta didik ini berdasarkan alamat pada kartu keluarga atau Surat Keterangan domisili dari RT/RW yang dilegalisir oleh Lurah/Kades setempat, yang diterbitkan paling singkat 6 bulan sebelum pelaksanaan PPDB. Dimana kuota $90 \%$ jalur zonasi ini sudah termasuk bagi peserta didik dari keluarga ekonomi tidak mampu atau Gakin (Keluarga Miskin) dengan proporsi jalur zona $70 \%$ dan jalur Gakin $20 \%$. Kuota $10 \%$ sisanya dibagi menjadi $5 \%$ jalur prestasi dalam zona dan 5\% jalur prestasi luar zona. Hal ini karena kuota jalur perpindahan orang tua/wali di SMAN 1 Surakarta tidak terpenuhi 5\%, sehingga kuota jalur orang tua/wali tersebut dialihkan ke dalam jalur prestasi.

\section{Perubahan Pasca Pemberlakuan Sistem Zonasi di SMAN 1 Surakarta}

Dilihat dari perbedan sistem yang digunakan sebelum sistem zonasi ini diberlakukan, SMAN 1 Surakarta masih memprioritaskan nilai atau prestasi calon peserta didik sebagai pertimbangan utama proses seleksi PPDB. Dimana seleksi yang memprioritaskan nilai siswa ini terakhir diberlakukan pada siswa angkatan tahun 2017/2018 atau yang saat ini duduk di bangku kelas XII. Sehingga jika dilihat dari nilai yang masuk, secara akademis kemampuan siswa dalam menyerap pelajaran masih relatif homogen. Berbeda setelah sistem zonasi ini diterapkan, nilai tidak lagi menjadi penentu siswa diterima di sekolah atau tidak. Prioritas utama siswa diterima di sekolah adalah berdasarkan zona atau jarak terdekat tempat tinggal siswa dengan sekolah. Hal ini berdampak pada input siswa yang masuk di SMAN 1 Surakarta. Seperti yang diungkapkan oleh guru X bahwa, sekolah harus beradaptasi dimana input yang masuk itu lebih heterogen lagi. Mulai dari kemampuan yang sedang, tinggi, ada juga yang relatif kurang. Oleh karena itu, ada pendekatan-pendekatan yang harus dipahami oleh guru untuk bisa menjangkau semuanya. Artinya perlu ada penyesuaianpenyesuaian. Jadi otomatis kita juga harus menyesuaikan karakteristik siswa dalam hal penyampaian materi.

Perubahan sistem PPDB yang mengakibatkan perubahan input siswa tersebut turut berdampak pada perubahan budaya sekolah dan pola pembelajaran di SMAN 1 Surakarta. Perubahan ini tidak hanya berdampak pada guru, namun juga siswa, wakil kepala sekolah, bahkan kepala sekolah. Budaya sekolah di SMAN 1 Surakarta adalah proses penanaman nilai dan norma yang berusaha di internalisasikan melalui pembiasaan-pembiasaan yang dilakukan oleh berbagai elemen di sekolah seperti guru, wakil kepala sekolah, dan kepala sekolah kepada para siswa. Budaya sekolah di SMAN 1 Surakarta yang sejak lama ditanamkan oleh warga sekolah adalah budaya 5S (Senyum, Sapa, Salam, Sopan, dan Santun). Para siswa dibiasakan untuk berperilaku sesuai dengan budaya $5 \mathrm{~S}$ tersebut agar dapat menghargai orang lain dan beradab dalam berperilaku. Hal ini karena pembentukan sikap dan karakter penting ditanamkan kepada seluruh siswa.

Selain 5S, sikap kritis dan tanggap terhadap hal-hal di sekitar maupun isu-isu terkini ditanamkan oleh sekolah sejak siswa memasuki Masa Orientasi Siswa (MOS) atau yang sekarang 
dikenal dengan Masa Pengenalan Lingkungan Sekolah (MPLS). Sikap kritis dan tangap ini antara lain ditanamkan melalui budaya literasi yang biasa dikenal dengan Gerakan Literasi Sekolah (GLS). Sesuai dengan Permendikbud Nomor 23 tahun 2015 tentang Gerakan Literasi Sekolah (GLS), GLS merupakan program yang wajib dilaksanakan oleh sekolah yang diawali dengan gerakan 15 menit membaca sebelum Kegiatan Belajar Mengajar (KBM) dimulai. Hal ini mendorong siswa untuk dapat belajar mandiri dan memiliki kesadaran disiplin belajar yang tinggi akan tanggung jawabnya sebagai siswa.

Budaya sekolah yang terbentuk juga diwariskan turun-temurun dari alumni-alumni SMAN 1 Surakarta. Contohnya, banyak siswa di kelas XII yang senang melakukan colut atau bolos saat jam pelajaran. Siswa-siswa tersebut biasanya colut untuk mengejar materi yang ketinggalan karena kesibukan organisasi atau ketika ada mata pelajaran yang tidak mengharuskan mereka untuk mengikuti pelajaran di sekolah, karena mereka merasa lebih produktif ketika belajar mandiri. Siswasiwa tersebut biasanya colut untuk belajar bersama atau ke tempat bimbel (Bimbingan Belajar), Perpusda (Perpustakaan Daerah), McD, KFC, atau tempat lain yang bisa membuat mereka belajar lebih nyaman. Bagi mereka, mood belajar saat colut dan di sekolah atau bahkan saat hari libur itu berbeda. Ketika colut mereka merasa lebih tertekan hati dan pikirannya. Terdapat tanggung jawab dan waktu yang telah mereka korbankan. Muncul semacam pola pikir yang telah terbentuk seperti "aku mosok colut ga oleh opo-opo, sedangkan koncoku iso oleh ilmu neng sekolah", sehingga mereka lebih semangat belajar ketika colut, bahkan pernah satu kelas yang masuk tidak sampai selusin.

Guru-guru yang mengetahui jika ada siswa kelas XII yang colut merasa sudah lumrah karena itu merupakan hal biasa yang dilakukan oleh siswa-siswa kelas XII di SMAN 1 Surakarta dari tahun ke tahun. Walaupun sering colut, mereka tetap masih menjaga sopan santun dan menaruh hormat kepada guru-guru, misalnya ketika terdapat guru yang memiliki pendekatan yang tepat saat mengajar seperti cara mengajarnya asik atau dekat dengan murid dan tetap mengedepankan efektifitas dalam pembelajaran, mereka tidak akan colut. Melalui pembiasaan-pembiasaan yang ditanamkan tersebut, maka dengan sendirinya akan membentuk karakter dan menciptakan kesadaran akan tanggung jawabnya sebagai siswa. Karena siswa-siswa tersebut memiliki orientasi pendidikan ke depan untuk mempersiapkan dirinya agar tidak hanya siap ketika mengikuti ujian atau lulus dengan cemerlang, namun juga dapat diterima di Perguruan Tinggi Negeri (PTN) yang di inginkan.

Budaya yang berbeda muncul setelah sistem zonasi diterapkan. Akibat input siswa yang masuk melalui sistem zonasi menjadi lebih heterogen, maka terdapat perbedaan sikap atau perilaku dan karakter siswa. Seorang wakil kepala sekolah bidang kurikulum menYatakan bahwa prestasi ternyata berkaitan dengan karakter, sehingga guru harus memahami banyak sekali karakter agar KBM (Kegiatan Belajar Mengajar) menjadi maksimal. Karakter siswa kelas X dengan kelas XII ini ternyata berbeda. Budaya colut yang biasanya dilakukan oleh siswa kelas XII untuk mengejar materi dan belajar mandiri, turut dilakukan oleh siswa yang masih duduk di kelas X. Hal ini turut menimbulkan beberapa masalah yang dialami oleh siswa kelas X.

Siswa kelas $\mathrm{X}$ yang sering colut atau bolos biasanya dipengaruhi oleh lingkungan pertemanannya. Mereka colut untuk bermain game atau terdapat mata pelajaran yang tidak disukai. Permasalahan lainnya adalah tidak semua siswa yang masuk di SMAN 1 Surakarta melalui sistem zonasi ini murni karena keinginannya sendiri. Terdapat siswa SMAN 1 Surakarta yang masuk atas keinginan orang tuanya, sehingga membuat mereka tidak sepenuhnya memiliki semangat belajar di SMAN 1 Surakarta. Dalam lain kasus, terdapat siswa yang harus berhenti sekolah akibat konflik dengan orang tuanya. Sebelum siswa tersebut memutuskan untuk akhirnya keluar sekolah, pihak sekolah yang dalam hal ini diwakili oleh guru Bimbingan Konseling (BK) telah melakukan home visit ke rumah siswa yang bersangkutan. Setelah melalui beberapa problem solving yang ditawarkan, ternyata orang tua siswa tersebut yang juga sebagai single parent tidak support anaknya untuk sekolah.

Stereotip yang muncul terhadap siswa yang masuk melalui sistem zonasi ini adalah memiliki sikap atau perilaku yang kurang baik. Selain itu, dari segi kemampuan akademis juga lebih rendah jika dibandingkan dengan siswa yang masuk melalui proses seleksi murni menggunakan nilai. Akibatnya, muncul labelling siswa zonasi dengan non zonasi. Labelling tersebut turut berpengaruh terhadap sikap dan perilaku anak. Siswa zonasi merasa dibanding-bandingkan dengan siswa non zonasi yang pada akhirnya terdapat siswa yang masuk melalui jalur zonasi ini sering merasa down 
dan tidak mampu menyesuaikan diri untuk belajar di SMAN 1 Surakarta. Pola pembelajaran yang ada di SMAN 1 Surakarta dapat dikatakan sangat kompetitif. Siswa tidak hanya dituntut untuk berhasil dan memiliki kemampuan di bidang akademis saja, namun juga non akademis. Dalam setiap mata pelajaran, seluruh siswa diuji kreatifitasnya. Siswa dididik untuk bersaing dan berprinsip dengan mengedepankan sikap dan perilaku siswa seperti kejujuran untuk berkompetisi secara sehat.

Pola pembelajaran di SMAN 1 Surakarta yang telah terbentuk tersebut mengalami perubahan saat sistem zoansi ini diterapkan. Motivasi belajar yang dimiliki oleh anak-anak di kelas X lebih rendah jika dibandingkan dengan kelas di atasnya. Hal ini dibuktikan dengan nilai yang dicapai mengalami penurunan dan beberapa mata pelajaran yang tidak tuntas. Bahkan dalam beberapa kasus, terdapat siswa yang pindah sekolah akibat merasa dirinya tidak mampu mengikuti kompetisi belajar dan menyesuaikan diri di lingkungan SMAN 1 Surakarta. Akan tetapi, tidak semua siswa yang masuk melalui jalur zonasi memiliki nilai yang rendah, ada juga yang berprestasi dan memiliki nilai tinggi, sehingga anak-anak dengan nilai tinggi ini kadang merasa harus bersaing dengan dirinya sendiri akibat pola belajar di kelasnya memiliki daya saing yang rendah. Anak-anak yang berprestasi atau memiliki nilai tinggi harus menentukan targetnya sendiri jika ingin maju dan memiliki pencapaian akademik tinggi. Akibat berbagai perubahan yang ditimbulkan dari pemberlakuan sistem zonasi tersebut, maka SMAN 1 Surakarta menentukan beberapa langkah dan strategi yang harus diambil agar tetap dapat mempertahankan mutu sekolah dan memberikan pelayanan terbaiknya kepada siswa-siswa di SMAN 1 Surakarta. Adapun strategi tersebut digambarkan melalui skema yang dapat dilihat pada Gambar 1.

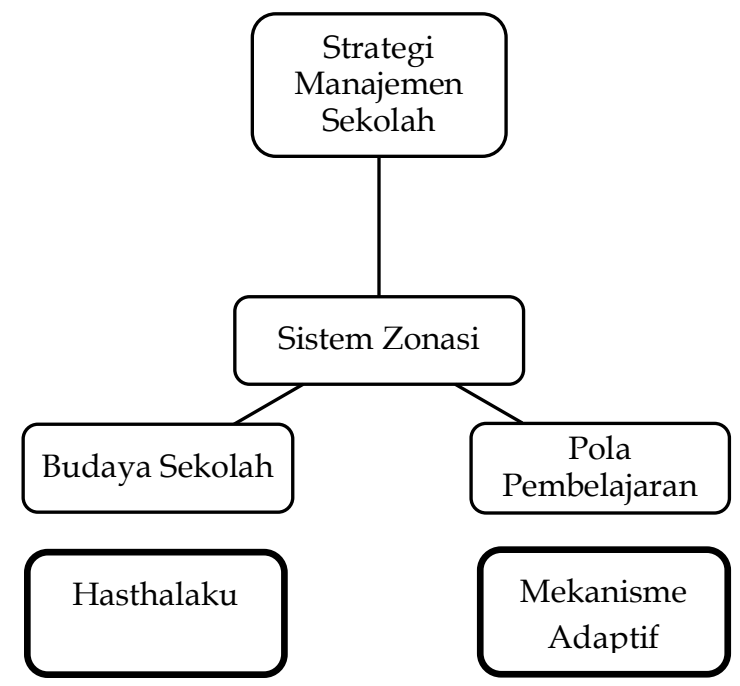

Gambar 1. Strategi Manajemen Sekolah dalam Menghadapi Pemberlakuan Sistem Zonasi

\section{Hasthalaku Sebagai Program Penanaman Nilai di Sekolah}

Manajemen sekolah di SMAN 1 Surakarta yang terdiri dari berbagai unsur seperti siswa, guru, kepala sekolah, dan komite sekolah telah menentukan beberapa strategi akibat perubahanperubahan yang muncul pasca pemberlakuan sistem zonasi. Dalam kaitannya untuk menghadapi perubahan budaya sekolah, melalui kerja sama dengan Solo Bersimfoni dan beberapa dosen dari Universitas Sebelas Maret (UNS), SMAN 1 Surakarta bersama dengan SMAN 6 Surakarta ditunjuk sebagai pilotting project yang menerapkan program Hasthalaku di sekolah. Oleh karena itu, SMAN 1 Surakarta termasuk sekolah adipangastuti yang mengimplementasikan program hasthalaku.

Program hasthalaku tersebut merupakan bagian dari Penguatan Pendidikan Karakter (PPK) siswa. Sekolah tidak hanya berperan sebagai sarana lembaga untuk mentransfer ilmu pengetahuan, namun juga mendidik dan membentuk karakter siswa melalui nilai-nilai yang ditanamkan dalam hasthalaku tersebut. Nilai-nilai itu meliputi tepa selira (tenggang rasa), pangerten (saling meng- 
hargai), lembah manah (rendah hati), guyub rukun (kerukunan), gotong royong (saling membantu), grapayak semanak (ramah tamah), ewuh perkewuh (saling menghargai), dan andhap asor (berbudi luhur). Nilai-nilai tersebut dipraktikkan dalam kegiatan sehari-hari di sekolah, misalnya ketika siswa bertemu gurunya menunduk, masuk kelas harus mengetuk pintu, salam terlebih dahulu, cara berbicara, dan lain-lain. Hal-hal tersebut terus-menerus dibiasakan dan tidak dapat dilakukan oleh satu orang, semua warga sekolah turut bersama-sama terlibat dalam mengimplementasikan hasthalaku. Menurut Ketua komunitas Solo Bersimfoni, Solo Bersimfoni menjadikan hasthalaku sebagai sebuah identitas gerakan yang bersumber dari budaya lokal, sehingga hal ini mendorong anak-anak muda untuk bersikap wong jawa ora ilang jawane.Inovasi Gerakan Literasi Sekolah (GLS) sebagai upaya mempertahankan budaya sekolah. Inovasi yang dilakukan dalam program Gerakan Literasi Sekolah (GLS) juga menjadi strategi sekolah dalam menghadapi perubahan budaya sekolah yang terjadi. GLS yang awalnya hanya dilakukan sebatas kegiatan literasi 15 menit sebelum Kegiatan Belajar Mengajar (KBM) dimulai, mulai tahun pelajaran 2019/2020 koordinator GLS di SMAN 1 Surakarta melakukan beberapa gebrakan untuk program ini. Inovasi yang dilakukan adalah dalam satu minggu, terdapat beberapa kegiatan yang berusaha dibiasakan oleh sekolah kepada para siswa.

Pada hari senin, terdapat kegiatan senin presrasi dan literasi bahasa. Senin Prestasi ditujukan kepada siswa kelas XII dengan melakukan Try Out (TO) rutin untuk persiapan UTBK khusus. Kegiatan literasi bahasa dilakukan oleh siswa kelas X dan XII dengan cara berpidato dalam bahasa Inggris setelah upacara bendera. Pada hari selasa sampai dengan hari kamis, terdapat literasi keagamaan. Setiap 15 menit pertama sebelum KBM dimulai, siswa yang beragama Islam melakukan tadarus di kelas, kemudian bagi siswa yang beragama Kristen melakukan kebaktian, sedangkan bagi siswa yang beragama Katolik, Hindu, dan Budha melakukan diskusi bersama di ruang agama masing-masing. Setiap hari jum'at minggu pertama, kegiatan yang dilakukan dibagi menjadi jum'at bersih, jum'at religi, dan jum'at sehat. Setiap jum' at minggu kedua terdapat kegiatan Jum'at Beraksi. Pada minggu pertama, jum'at bersih dilakukan oleh siswa kelas $\mathrm{X}$ yang bergotong royong membersihkan sekolah dengan membawa alat-alat kebersihan. Jumat religi dilaksanakan oleh siswa kelas XI dengan mengikuti pengajian di aula sekolah, sementara yang non islam beribadah di ruang ibadah masing-masing. Jum'at sehat ditujukan kepada siswa kelas XII yang melakukan kegiatan senam di lapangan. Seluruh kegiatan yang ada pada hari jum'at minggu pertama tersebut dilakukan secara bergantian atau rolling per angkatan.

Kegiatan yang dilakukan pada minggu kedua, yaitu jum'at beraksi dilakukan dengan cara berpendapat kritis melalui tulisan. Siswa kelas XII di instruksikan untuk membaca novel kemudian menulisnya dalam bentuk resensi yang di jilid dan dijadikan buku-buku kumpulan resensi novel. Sedangkan untuk siswa kelas X dan kelas XI membuat jurnal baca dari buku-buku (non pelajaran) yang sudah mereka baca. Seluruh tulisan mereka diberlakukan plagiarism checked untuk menghindari kecurang-kecurangan yang dilakukan oleh siswa. Pemberlakuan plagiarism checked yang dilakukan oleh sekolah bertujuan agar siswa dapat bersikap jujur dan berkompetisi dengan cara yang sehat.

\section{Mekanisme Adaptif Pola Pembelajaran Sesuai Karakteristik dan Kemampuan Siswa}

Kegiatan akademik siswa ditangani oleh guru-guru yang harus berdadaptasi dan merubah pola pembelajarannya sesuai karakteristik siswa ketika sistem zonasi ini diterapkan. Perbedaan pola pembelajaran yang diterapkan pada sistem zonasi adalah terletak pada metode penyampaian pembelajaran dan penentuan cakupan materi pembelajaran dalam tiap pertemuan. Salah satu guru $X$ mengatakan bahwa, para siswa meminta metode penyampaian pembelajaran yang bertahap dan tidak terlalu cepat. Sebagian dari siswa perlu waktu untuk menuliskan materi di buku catatan, sebelum lanjut kepada tahapan materi berikutnya. Di samping itu, cakupan materi pembelajaran dalam tiap pertemuan juga disesuaikan dengan kondisi siswa di dalam kelas. Satu topik pembahasan yang biasanya dapat diselesaikan dalam satu pertemuan, bisa jadi berlanjut pada pertemuan berikutnya. Dengan demikian, kepala sekolah menganggap bahwa mengubah mindset guru memang penting. Dari yang awalnya guru melihat siswa dengan kemampuan dan karakter yang relatif homogen, menjadi guru harus menyadari bahwa siswa merupakan individu yang unik dengan kemampuan dan karakteristik beragam yang tidak dapat digeneralisasi, sehingga pola pemberlajaran yang diterapkan juga harus sesuai dengan karakteristik siswa. 
Selain itu, beberapa guru juga menyediakan waktu atau memberikan nomor WhastApp kepada siswanya jika ada yang belum paham akan materi yang disampaikan dan dapat bertanya di luar jam pelajaran. Sistem manajemen sekolah di SMAN 1 Surakarta selain harus melakukan adaptasi dengan mengubah pola pembelajaran oleh guru, sekolah juga telah mengadakan wacana dan sosialisasi untuk program Sistem Kredit Semester (SKS) selain program paket yang sudah diterapkan untuk Kurikulum 2013 di sekolah. Dalam Peraturan Menteri Pendidikan dan Kebudayaan Republik Indonesia Nomor 158 Tahun 2014 tentang Penyelenggaraan Sistem Kredit Semester (SKS) pada Pendidikan Dasar dan Menengah Pasal 1 menyebutkan bahwa Sistem Kredit Semester atau SKS adalah bentuk penyelenggaraan pendidikan yang peserta didiknya menyepakati jumlah beban belajar yang diikuti dan/atau strategi belajar setiap semester pada satuan pendidikan sesuai dengan bakat, minat, dan kemampuan/kecepatan belajarnya (Kemdikbud RI, 2017, p. 5).

Selama ini, alasan SMAN 1 Surakarta belum menerapkan SKS adalah karena siswa-siswa di SMAN 1 Surakarta masih relatif homogen. Namun semenjak sistem zonasi diterapkan, SMAN 1 Surakarta merasa perlu untuk menerapkan SKS. Sekolah berusaha melakukan adaptasi atas perubahan yang muncul setelah pemberlakuan sistem zonasi ini dengan cara memfasilitasi heterogenitas kemampuan atau kecepatan belajar siswa yang beragam melalui program pembelajaran dengan SKS. Dimana rentang waktu pendidikan atau lama belajar yang dibutuhkan adalah selama 2-4 tahun. Hal ini bisa dilihat sebagai langkah sekolah untuk melakukan diversifikasi kualitas siswa yang ada. Saat ini pihak sekolah telah melakukan sosialisai kepada siswa dan orang tua siswa mengenai program SKS yang rencananya akan diterapkan tahun ajaran 2020/2021. Setelah sosialiasai dilakukan, sekolah masih dalam proses administrasi untuk selanjutnya diajukan ijin kepada Dinas Pendidikan dan Kebudayaan Provinsi Jawa Tengah.

Pembahasan

Sekolah merupakan lembaga pendidikan dengan salah satu tujuannya adalah mensosialisasikan generasi muda menjadi anggota masyarakat untuk dijadikan tempat pembelajaran, mendapatkan pengetahuan, perubahan perilaku, dan penguasaan tata nilai. Dalam pandangan struktural fungsional, masyarakat dilihat sebagai suatu sistem sosial yang terdiri atas unsur-unsur atau elemenelemen yang saling berkaitan. Perubahan yang terjadi pada suatu unsur atau elemen tertentu, akan berdampak pada perubahan unsur atau elemen lainnya. Pandangan ini juga menekankan pada peran dan fungsi struktur sosial yang menitikberatkan pada konsensus atau kesepakatan bersama dalam masyarakat (Maunah, 2016, p. 159). Begitu halnya ketika sistem zonasi sebagai sebuah sistem yang baru diterapkan dalam dunia pendidikan. Sekolah sebagai lembaga pendidikan seperti SMAN 1 Surakarta yang memiliki struktur organisasi di dalamnya diketahui telah mendapatkan pengaruh atas pemberlakuan sistem zonasi yang berdampak pada beberapa perubahan dan proses adaptasi untuk mempertahankan struktur tersebut. Istilah struktur sosial dalam hal ini digunakan untuk menunjukkan jaringan yang kompleks dalam hubungan sosial (Radcliffe-Brown, 1952, p. 188).

Jaringan yang terbentuk dalam struktur manajemen sekolah di SMAN 1 Surakarta tersusun atas berbagai unsur atau elemen yang saling berhubungan dan memiliki keterkaitan. Elemen-elemen tersebut antara lain terdiri atas kepala sekolah, wakil kepala sekolah, guru, siswa, serta komite sekolah. Setiap elemen dalam struktur tersebut memiliki peran dan fungsi sesuai dengan statusnya masing-masing. Kepala sekolah dalam hal ini berperan sebagai manajer sekolah yang bertugas untuk mengkoordinasikan seluruh elemen dalam struktur manajemen sekolah agar berjalan dan bekerja sesuai dengan fungsinya, misalnya ketika pemberlakuan sistem zonasi di SMAN 1 Surakarta mengakibatkan perubahan budaya sekolah dan pola pembelajaran yang ada, maka kepala sekolah sebagai komando bersama dengan wakil kepala sekolah, guru, atau bahkan dapat membentuk hubungan maupun jaringan sosial yang lebih luas kepada komite sekolah serta pihak eksternal untuk menentukan langkah-langkah atau strategi dalam menghadapi perubahan atas pemberlakuan sistem zonasi tersebut.

Jika dalam penelitian yang dilakukan oleh Chan, et al. (2019) tentang sistem zonasi mengungkapkan bahwa terdapat dampak positif dan negatif dari sistem zonasi terhadap penerimaan peserta didik baru. Dimana dampak positifnya adalah menghilangkan label sekolah favorit dan non favorit, serta dampak negatifnya adalah sulitnya bagi wali murid untuk mendaftarkan anaknya di 
sekolah karena pandaftaran yang dilaksanakan secara online, sehingga terkesan rumit. Secara lebih spesifik penelitian ini menunjukkan bahwa sistem zonasi juga berdampak pada perubahan-perubahan yang terjadi di sekolah. Perubahan tersebut meliputi perubahan budaya sekolah dan pola pembelajaran.

Hasthalaku sebagai salah satu langkah sekolah untuk menghadapi perubahan budaya sekolah muncul karena jaringan kerjasama yang dibangun antara SMAN 1 Surakarta dengan beberapa pihak eksternal seperti Solo Bersimfoni dan Universitas Sebelas Maret. Dalam menjalin kerjasama tersebut, wakil kepala sekolah bidang kehumasan juga berperan penting sebagai gerbang fasilitator yang menghubungkan sekolah dengan pihak eksternal. Jika salah satu elemen atau unsur dalam struktur manajemen sekolah tersebut tidak berfungsi, maka akan mempengaruhi kondisi struktur yang ada secara keseluruhan. Proses penanaman nilai-nilai dalam hasthalaku tidak akan berhasil jika siswa tidak mengetahui dan menerapkan nilai-nilai yang ada dalam kehidupan seharihari di sekolah. Pembiasaan tentang nilai-nilai dalam hasthalaku yang secara terus menerus dilakukan juga tidak akan bertahan lama jika guru tidak mencerminkan perilaku yang sesuai dengan hasthalaku tersebut.

Selain hasthalaku, inovasi yang dilakukan SMAN 1 Surakarta terhadap program Gerakan Literasi Sekolah (GLS) juga dapat dilihat sebagai bagian dari strategi sekolah dalam mempertahankan budaya sekolah. Budaya dalam pandangan Radcliffe-Brown (1952) dilihat sebagai mekanisme adaptif yang membuat manusia atau elemen-elemen dalam manajemen sekolah mampu menjaga kehidupan sosial sebagai suatu komunitas yang teratur. Mekanisme adaptif yang dilakukan oleh SMAN 1 Surakarta juga berkaitan dengan adanya perubahan pola pembelajaran setelah sistem zonasi diterapkan. Guru mengubah pola pembelajaran dan melakukan adaptasi sesuai dengan kultur kelas dengan masing-masing siswa yang memiliki keberagaman sifat, karakter, dan kemampuan dalam menyerap materi pembelajaran. Hal ini dapat dilihat sebagai fungsi yang dimiliki oleh seseorang dengan status sebagai guru. Guru memiliki peranan yang dimainkan atau kontribusi yang diberikan dalam proses pembelajaran demi keberjalanan struktur tersebut.

Berbagai strategi yang dilakukan oleh manajemen sekolah dalam menghadapi pemberlakuan sistem zonasi di SMAN 1 Surakarta tersebut terbentuk berdasarkan konsensus atau kesepakatan bersama dengan elemen-elemen manajemen sekolah yang ada. Konsensus itulah yang mengintegrasikan warga sekolah dalam struktur sosial yang lebih mapan sehingga tercipta keteraturan. Melalui perspektif struktural fungsional, disini kita dapat melihat jika masyarakat dalam suatu struktur sosial mengalami perubahan, maka akan muncul cara atau strategi yang berkembang secara lebih baik untuk mengatasi perubahan tersebut (Maunah, 2016, p. 160).

\section{SIMPULAN}

Pemberlakuan sistem zonasi di SMAN 1 Surakarta menimbulkan berbagai perubahan yang ada seperti perubahan budaya sekolah dan pola pembelajaran. Berbagai perubahan yang timbul akibat pemberlakuan sistem zonasi inilah yang membuat manajemen sekolah di SMAN 1 Surakarta menentukan berbagai langkah dan strategi guna mempertahankan dan memperbaiki kualitas mutu pendidikan. Strategi yang dilakukan oleh manajemen sekolah di SMAN 1 Surakarta dalam menghadapi perubahan budaya sekolah adalah melalui proses penanaman nilai-nilai yang terdapat dalam hasthalaku. Hasthalaku adalah sebuah identitas gerakan yang bersumber dari budaya lokal untuk membentuk karakter serta perilaku siswa dalam kegiatan sehari-hari di sekolah. Selain itu, inovasi Gerakan Literasi Sekolah (GLS) juga dilakukan oleh sekolah untuk mempertahankan budaya sekolah agar siswa tetap bersikap kritis dan tanggap terhadap hal-hal di sekitar maupun isu-isu terkini.

Perubahan pola pembelajaran yang terjadi di SMAN 1 Surakarta dilakukan menggunakan mekanisme adaptif oleh elemen-elemen yang terdapat dalam manajemen sekolah seperti guru, kepala sekolah, siswa, serta komite sekolah. Mekanisme adaptif dilakukan melalui proses penyesuaian dan perubahan cara mengajar guru dengan melihat karakteristik dan kemampuan masing-masing siswa yang beragam atau heterogen. Selain itu untuk merespon heterogenitas siswa, sekolah juga telah mengadakan wacana dan sosialisasi untuk penerapan program Sistem Kredit Semester (SKS) yang rencananya akan diterapkan pada tahun ajaran baru. SKS bertujuan untuk memfasilitasi kecepatan belajar siswa yang beragam dengan lama belajar 2-4 tahun. 
Perubahan budaya sekolah dan pola pembelajaran tidak cukup jika ditanggapi melalui strategi-strategi yang di implementasikan di sekolah seperti hasthalaku, inovasi Gerakan Literasi Sekolah (GLS), mekanisme adaptif, ataupun wacana Sistem Kredit Semester (SKS). Melihat berbagai permasalahan yang dihadapi, kepala sekolah perlu menekankan perubahan mindset guru seperti menghilangkan pandangan-pandangan atau labelling siswa zonasi dan non zonasi. Guru membutuhkan kecerdasan personal untuk melihat siswa sebagai sosok yang unik bukan hanya saat belajar di kelas, namun sebagai individu yang memiliki sikap dan karakter berbeda.

\section{DAFTAR PUSTAKA}

Adiputra, A. R., Karsidi, R., \& Haryono, B. (2019). Cultural lag dalam program Penerimaan Peserta Didik Baru (PPDB) online dengan sistem zonasi tahun 2018 di Sekolah Menengah Atas Negeri 2 Sukoharjo. Habitus : Jurnal Pendidikan, Sosiologi, dan Antropologi, 3(1), 1-13. doi: https://doi.org/10.20961/habitus.v3i1.30906

Chan, F., Rimba, A., Setiawati, R., Nurfitriana, Dawiyah, Nurlayly, C., \& Nandatulloh. (2019). Dampak sistem zonasi terhadap penerimaan peserta didik baru. Dikdas Matappa: Jurnal Ilmu Pendidikan Dasar, 2(2), 326-330. doi: https://dx.doi.org/10.31100/dikdas.v2i2.465

Danim, S. (2010). Otonomi manajemen sekolah. Bandung: Alfabeta.

Dinas Pendidikan dan Kebudayaan Provinsi Jawa Tengah. (2019). Peraturan Dinas Pendidikan dan Kebudayaan Provinsi Jawa Tengah Nomor 421/07651 tentang Petunjuk Teknis Penerimaan Peserta Didik Baru (PPDB) pada Sekolah Menengah Atas (SMA) dan Sekolah Menengah Kejuruan (SMK) Negeri Provinsi Jawa Tengah Tahun Pelajaran 2019/2020.

Hasbullah, H., \& Anam, S. (2019). Evaluasi kebijakan sistem zonasi dalam Penerimaan Peserta Didik Baru (PPDB) di tingkat Sekolah Menengah Pertama Negeri (SMPN) di Kabupaten Pamekasan. Reformasi, 9(2), 112-122. doi: http://dx.doi.org/10.33366/rfr.v9i2.1413

Izzah, A., \& Harmanto. (2013). Penanaman Nilai-Nilai Antikorupsi Melalui Budaya Sekolah di SMPN 38 Surabaya. Kajian Moral dan Kewarganegaraan, 2(1), 268-283. Retrieved from https://jurnalmahasiswa.unesa.ac.id/index.php/jurnal-pendidikankewarganegaraa/article/view/3621

Kementerian Pendidikan dan Kebudayaan Republik Indonesia. (2014). Peraturan Kementerian Pendidikan dan Kebudayaan Republik Indonesia Nomor 158 Tahun 2014 tentang Penyelenggaraan Sistem Kredit Semester (SKS) pada Pendidikan Dasar dan Menengah.

Kementerian Pendidikan dan Kebudayaan Republik Indonesia. (2017). Peraturan Kementerian Pendidikan dan Kebudayaan Republik Indonesia Nomor 17 Tahun 2017 tentang Penerimaan Peserta Didik Baru (PPDB).

Kementerian Pendidikan dan Kebudayaan Republik Indonesia. (2017). Peraturan Kementerian Pendidikan dan Kebudayaan Republik Indonesia Nomor 23 Tahun 2015 tentang Gerakan Literasi Sekolah (GLS).

Kementerian Pendidikan dan Kebudayaan Republik Indonesia. (2017). Pedoman penyelenggaraan Sistem Kredit Semester (SKS) di SMA. Jakarta.

Kementerian Pendidikan dan Kebudayaan Republik Indonesia. (2018). Peraturan Kementerian Pendidikan dan Kebudayaan Republik Indonesia Nomor 51 Tahun 2018 tentang Penerimaan Peserta Didik Baru (PPDB) pada Taman Kanak-Kanak (TK), Sekolah Dasar (SD), Sekolah Menengah Pertama (SMP), Sekolah Menengah Atas (SMA), dan Sekolah Menengah Kejuruan (SMK).

Kementerian Pendidikan dan Kebudayaan Republik Indonesia. (2019). Peraturan Kementerian Pendidikan dan Kebudayaan Republik Indonesia Nomor 20 Tahun 2019 tentang Penerimaan Peserta Didik Baru Pada Taman Kanak-Kanak, Sekolah Dasar, Sekolah Menengah Pertama, Sekolah Menengah Atas, Dan Sekolah Menengah Kejuruan. 
136 - Jurnal Akuntabilitas Manajemen Pendidikan

Kementerian Pendidikan dan Kebudayaan Republik Indonesia. (2019). Peraturan Kementrian Pendidikan dan Kebudayaan Republik Indonesia Nomor 44 Tahun 2019 tentang Penerimaan Peserta Didik Baru Pada Taman Kanak Kanak, Sekolah Dasar, Sekolah Menengah Pertama, Sekolah Menengah Atas, dan Sekolah Menengah Kejuruan.

Kementerian Pendidikan dan Kebudayaan Republik Indonesia. (2020). Tentang jalur zonasi minimal $50 \%$ pada PPDB tahun ajaran 2020/2021. Retrieved from https://p4tkbmti.kemdikbud.go.id/main/2020/01/23/tentang-jalur-zonasi-minimal-50-padappdb-tahun-ajaran-2020-2021/

Maunah, B. (2016). Pendidikan dalam perspektif struktural fungsional. Cendekia: Jurnal Pendidikan dan Pembelajaran, 10(2), 159-178. doi: https://doi.org/10.30957/cendekia.v10i2.136

Pratiwi, Y. M. (2019, November 2). Pro dan kontra penerapan sistem zonasi dalam PPDB Tahun $2019 . \quad$ Kompasiana. Retrieved from https://www.kompasiana.com/mila89663/5dbd2bec097f3610c04b43f2/pro-dan-kontrapenerapan-sistem-zonasi-dalam-ppdb-tahun-2019?page $=$ all

Radcliffe-Brown, A. R. (1952). Structure and function in primitive society. London: Routledge and Kegan Paul.

Rohiat, R. (2012). Manajemen sekolah: Teori dasar dan praktik. Bandung: PT Refika Aditama.

Sulistiyoningrum, M. K. (2016). Strategi penerapan manajemen berbasis sekolah (Studi kasus di MI Nurul Islam Ngaliyan Semarang). Wahana Akademika: Jurnal Studi Islam dan Sosial, 3(1), 99-113. doi: http://dx.doi.org/10.21580/wa.v3i1.875

Tuindra, E., \& Sahuri, C. (2013). Implementasi strategi manajemen berbasis sekolah. Jurnal Administrasi Pembangunan, 1(2), 109-114. Retrieved from https://jap.ejournal.unri.ac.id/index.php/JAP/article/view/1343

Ulfatin, N. (2014). Metode penelitian kualitatif di bidang pendidikan: Teori dan aplikasinya. Malang: Bayumedia Publishing.

Widodo, H. (2017). Manajemen perubahan budaya sekolah. Manageria: Jurnal Manajemen Pendidikan Islam, 2(2), 287-306. doi: https://doi.org/10.14421/manageria.2017.22-05

Winarto, W., \& Prasojo, L. D. (2017). Strategi pengembangan budaya pembelajaran di sekolah. Jurnal Akuntabilitas Manajemen Pendidikan, 5(1), 109-121. doi: https://doi.org/10.21831/amp.v5i1.13092 